\title{
Differences in learning ability of two strains of Hemigrammus caudovittatus
}

\author{
ALEXANDER Y. ZHUIKOV \\ Lower Vertebrates Behavior Laboratory, A. N. Severtsov Institute of Evolutionary Morphology \\ and Ecology of Animals, U.S.S.R. Academy of Sciences, Moscow, U.S.S.R
}

(Vincent M. LoLordo, Sponsor)

\begin{abstract}
With the purpose of determining interstrain differences in learning ability of fishes, two aquarial strains of Buenos Aires tetra, Hemigrammus caudovittatus (Characinidae)-normally colored (25 subjects) and albino (13 subjects) - were tested. To determine learning ability, active avoidance in the shuttlebox was conditioned. The number of good and poor learners in each strain was determined, taking into account both the speed of appearance and the consolidation of the active avoidance response. Normally colored subjects had a higher percentage of good learners than did albino animals. However, these two strains did not differ in motor activity. Since the strains are easily distinguished visually, they are convenient for use in experiments in which comparision of behavior in good and poor learners living in a group together is the aim of study.
\end{abstract}

Genetically determined differences in learning ability between strains of one species would be useful in a variety of comparative investigations of learning. Typical examples of such animals commonly used in experiments on higher nervous activity are the strains of maze-bright and maze-dull rats bred by Tryon $(1929,1942)$ and a number of other strains of rats and mice (e.g., Lagerspetz \& Lagerspetz, 1975). Similar subjects within Pisces have not been found until recently.

Earlier attempts to find intraspecies differences in the learning ability of fish were either unsuccessful (Astaurova, 1985) or testified only to the connection between natural selection and enrichment of the environment on the one hand and intraspecies differences of behavior on the other hand (Leshcheva and Zhuikov, 1989; Zhuikov, 1986).

With the purpose of researching interstrain differences in learning ability of fish, two color morphs of Buenos Aires tetra, Hemigrammus caudovittatus (Characinidae), were chosen: the normally colored red-fin tetra and the albino morph, or lemon tetra (so called because of the yellow tint of its body).

\section{METHODS}

\section{Subjects and Maintenance}

The subjects were 25 red-fin tetras and 13 lemon tetras. All fish were obtained from Zoo-objedinenie (Moscow) as adults and, prior to experiments, were kept in a 200-liter aquarium, with a water temperature of $20^{\circ}-24^{\circ} \mathrm{C}$. During the experiments, the fish were kept individually in the shuttleboxes.

\section{Experimental Setups}

Learning was studied in the shuttleboxes $(30 \mathrm{~cm}$ long $\times 13 \mathrm{~cm}$ wide $\times 10 \mathrm{~cm}$ deep). Each box was divided by a transverse partition into

Correspondence should be addressed to Alexander Y. Zhuikov, Lower Vertebrates Behavior Laboratory, A. N. Severtsov Institute of Evolutionary Morphology and Ecology of Animals, U.S.S.R. Academy of Sciences, 33 Leninsky prospekt, Moscow 117071, U.S.S.R. two equal parts. The partition was slightly raised above the bottom, permitting the fish to move freely throughout the box.

\section{Learning}

The conditioned stimulus (CS) was switching on of two lamps (6 V), uniformly illuminating both compartments of the shuttlebox. The unconditioned stimulus (US) was an electric current (3-18 V, $50 \mathrm{~Hz})$, fed to the aluminum side walls of the shuttlebox by $0.1-\mathrm{sec}$ impulses separated by 2 -sec intervals. The electric current was individually controlled by the experimenter according to threshold of motor reaction of the fish. The CS preceded the US by $10 \mathrm{sec}$; in the absence of a response, the two stimuli continued for another $10 \mathrm{sec}$. Stimulation was stopped when the fish crossed from one compartment into another, either avoiding or escaping the shock. The intertrial interval was $7 \mathrm{~min}$. Each subject received $50 \mathrm{CS}$ presentations daily, and $100 \mathrm{CS}$ presentations in all.

Each individual obtained 50 trials daily, 150 trials in all. Criterion of end of learning process (consolidation of conditioned activity) was a serial of 10 avoidance reactions.

\section{Open Field}

Motor activity in the open field was determined after the end of learning. For this, the subject was placed into an opaque plastic cylinder $5 \mathrm{~min}$ before the test. The cylinder was in the center of a round glass tank (34 $\mathrm{cm}$ in diameter, with water $5 \mathrm{~cm}$ in depth). The bottom of the tank was divided into nine equal zones. Motor activity of the fish was observed using a video camera placed above the open field. Crossings of zone borders were registered during the 10 -min period after lifting of the cylinder. Information about crossings was input into microcomputer Elektronika BK 0010.01 through a remote keyboard in real time.

\section{RESULTS}

As shown in Table 1, the two tested morphs were not distinguished by motor activity in the open field. However, the average characteristics of learning did differ in the two strains: avoidance responses first appeared sooner, and the avoidance habit was consolidated significantly sooner, in the red-fin tetras than in the lemon tetras. In an analysis of interindividual differences in the dynamics of the learning process by methods, described in detail earlier (see Leshcheva \& Zhuikov, 1989; Zhuikov, 1984), 
Table 1

Characteristics of Learning Capacity of the Studied Fish Species

\begin{tabular}{crrccc}
\hline $\begin{array}{c}\text { Learning } \\
\text { Type }\end{array}$ & $\begin{array}{c}\text { No. Of } \\
\text { Subjects }\end{array}$ & $\%$ & $\begin{array}{c}\text { Appearance of } \\
\text { Conditioned Activity }\end{array}$ & $\begin{array}{c}\text { Consolidation of } \\
\text { Conditioned Activity }\end{array}$ & $\begin{array}{c}\text { Open-Field } \\
\text { Motor Activity }\end{array}$ \\
\hline & & & Red-Fin Tetra & & \\
1 & 4 & 16.00 & & & $300.50 \pm 87.84$ \\
2 & 11 & 44.00 & $20.73 \pm 4.05$ & $70.91 \pm 7.44$ & $433.82 \pm 69.54$ \\
3 & 10 & 40.00 & $10.60 \pm 2.54$ & $10.60 \pm 2.54$ & $332.20 \pm 60.41$ \\
Sum & 25 & 100.00 & $15.90 \pm 2.64$ & $42.19 \pm 7.82$ & $371.84 \pm 41.46$ \\
& & & Lemon Tetra & & \\
1 & 6 & 46.15 & & & $399.17 \pm 39.50$ \\
2 & 6 & 46.15 & $39.33 \pm 7.09$ & $91.67 \pm 8.30$ & $431.17 \pm 91.08$ \\
3 & 1 & 7.69 & 16 & 16 & 558 \\
Sum & 13 & 100.00 & $36.00 \pm 6.86$ & $80.86 \pm 12.90$ & $426.15 \pm 45.12$ \\
\hline
\end{tabular}

Note-Appearance of Conditioned Activity = quantity of presentations of conditioned stimulus (CS); Consolidation of Conditioned Activity = quantity of presentations of CS; Open-Field Motor Activity = quantity of grid crossings per $10 \mathrm{~min}$.

we calculated the relative number of subjects that failed to learn (Type 1, poor learners), the number of subjects that consolidated the habit after a period of unstable conditioned activity (Type 2, normal learners), and the number of subjects that formed the defensive habit suddenly, with the habit remaining stable (Type 3 , fast learners). It was found that there was a greater proportion of Type 3 subjects in the red-fin tetra strain than in the lemon tetra strain. Moreover, the proportion of Type 1 subjects was large (46.15\%; Table 1) among lemon tetras, but minimal (16.00\%) among red-fin tetras

\section{CONCLUSION}

The data presented in this paper has shown that, in Hemigrammus caudovittatus, two strains practically undistinguished by motor activity in open field are distinguished by learning ability. Red-fin tetras learn shuttlebox avoidance better than do lemon tetras. Since the strains are easily distinguished visually, they are convenient for use in experiments that compare the behavior of good and poor learners living in a group together.

\section{REFERENCES}

Astaurova, N. B. (1985). Sravnenie povedenija dvuch form serebrjannogo karasja raznoj ploidnosti. [Comparison of behavior of two strains of Carassius auratus.] Avtoref. diss. ... kand. biol. nauk. Moscow. 16 s.

LAGerspetz, K. Y. H., \& LAGersPetz, K. M. I. (1975). The search for mechanisms of behaviour through selective breeding experiments. Actualnyje problemy genetiki povedenija. L.: Nauka, 120-135. (In Russian)

LeshCheVA, T. S., \& Zhuikov, A. Y. (1989). Obutchenie ryb: ecologitcheskie i pricladnye aspecty. [Fish learning: Ecological and applied aspects.] M.: Nauka. 109 s.

TRYON, R. C. (1929). Genetics and learning ability in rats: Preliminary report. University of California Publications in Psychology, 4(No. 5), 71-89.

TrYon, R. C. (1942). Individual differences. In F. A. Moss (Ed.), Comparative psychology (pp. 330-365). New York: Prentice-Hall.

ZHUIKov, A. Y. (1984). Tipy povedenija molodi semgi v experimente po vyrabotke oboronitelnogo uslovnogo reflexa. [Types of young Atlantic salmon behavior in experiment of active avoidance reaction development.] Problemy izutch. i racional. ispolz. biol. resursov morey Evr. Severa i Sev. Atlantiki. Murmansk: PINRO, 49-51.

ZHUikov, A. Y. (1986). Osobennosti uslovnoreflectornoj dejatelnosti molodi atlantitcheskogo lososja v svjazi s problemoj vosproizvodstva. [Peculiarities of conditioned activity of young Atlantic salmon in connection with problem of reproduction. Summary of $\mathrm{PhD}$ thesis.] Avtoref. diss. ... kand. biol. nauk. Moscow. 20 s. 